\title{
Erratum to: Interaction between FTO gene variants and lifestyle factors on metabolic traits in an Asian Indian population
}

Karani S. Vimaleswaran ${ }^{1 *}$, Dhanasekaran Bodhini ${ }^{2}$, N. Lakshmipriya ${ }^{3}$, K. Ramya $^{2}$, R. Mohan Anjana ${ }^{2,3,4}$, Vasudevan Sudha ${ }^{3}$, Julie A. Lovegrove ${ }^{1}$, Sanjay Kinra ${ }^{5}$, Viswanathan Mohan ${ }^{2,3,4}$ and Venkatesan Radha ${ }^{2}$

\section{Erratum}

After publication of the original article [1], the authors noticed an error in the 'Acknowledgements' section. "(CURES-79)" should be "(CURES-137)". The correct 'Acknowledgements' section has been included in this erratum accordingly:

\section{Acknowledgements}

Dr Karani S Vimaleswaran acknowledges support from the British Nutrition Foundation. The study was supported by Lady Tata Memorial Trust, Mumbai. The Chennai Wellingdon Corporate Foundation supported the CURES field studies (CURES-137).

\footnotetext{
Author details

${ }^{1}$ Hugh Sinclair Unit of Human Nutrition and Institute for Cardiovascular and Metabolic Research (ICMR), Department of Food and Nutritional Sciences, University of Reading, Reading, UK. ${ }^{2}$ Department of Molecular Genetics, Madras Diabetes Research Foundation, Chennai, India. ${ }^{3}$ Department of Foods, Nutrition and Dietetics Research, Madras Diabetes Research Foundation, Chennai, India. ${ }^{4}$ Dr. Mohan's Diabetes Specialties Centre, WHO Collaborating Centre for Non-communicable Diseases Prevention and Control, Chennai, India. ${ }^{5}$ Department of Non-Communicable Disease Epidemiology, London School of Hygiene \& Tropical Medicine, London, UK.
}

Received: 7 June 2016 Accepted: 7 June 2016

Published online: 13 June 2016

\section{References}

1. Vimaleswaran et al. Interaction between FTO gene variants and lifestyle factors on metabolic traits in an Asian Indian population. Nutrition \& Metabolism. 2016;13:39. doi:10.1186/s12986-016-0098-6.

\footnotetext{
* Correspondence: v.karani@reading.ac.uk

${ }^{1}$ Hugh Sinclair Unit of Human Nutrition and Institute for Cardiovascular and Metabolic Research (ICMR), Department of Food and Nutritional Sciences, University of Reading, Reading, UK
}

(c) 2016 The Author(s). Open Access This article is distributed under the terms of the Creative Commons Attribution 4.0 International License (http://creativecommons.org/licenses/by/4.0/), which permits unrestricted use, distribution, and reproduction in any medium, provided you give appropriate credit to the original author(s) and the source, provide a link to the Creative Commons license, and indicate if changes were made. The Creative Commons Public Domain Dedication waiver (http://creativecommons.org/publicdomain/zero/1.0/) applies to the data made available in this article, unless otherwise stated.

Submit your next manuscript to BioMed Central and we will help you at every step:

- We accept pre-submission inquiries

- Our selector tool helps you to find the most relevant journal

- We provide round the clock customer support

- Convenient online submission

- Thorough peer review

- Inclusion in PubMed and all major indexing services

- Maximum visibility for your research

Submit your manuscript at
Biomed Central 